Proc. Estonian Acad. Sci. Eng., 2006, 12, 3-1, 230-237

\title{
Behaviour of wind power fronts
}

\author{
Teolan Tomson and Maire Hansen \\ Department of Materials Science, Tallinn University of Technology, Ehitajate tee 5, 19086 Tallinn, \\ Estonia; teolan@anet.ee \\ Received 14 April 2005, in revised form 13 March 2006

\begin{abstract}
An attempt is made to prove the principal difference between the distribution law of wind power increments and the corresponding law of the wind speed increments. The distribution law of wind power increments is close to an asymmetric triangle in the medium range and with zero values at low and high average values of the wind speed. The wind power increments found by the selected increment method are much more frequent than those determined by the simple increment method. The theoretical functional relations were proved, based on the real recorded wind power data.
\end{abstract}

Key words: wind power front, frequency distribution, power system.

\section{INTRODUCTION}

Practical application of wind energy for the electricity generation is a reality in Estonia in the 21st century and investigation of the wind quality has become actual. Wind energy depends on strong winds in the Moonsund archipelago and Estonian western costal line. The values and azimuths of strong winds have been studied in $\left.{ }^{1,2}\right]$. Unfortunately, strong winds are highly variable with high level of the wind speed increments $\left[^{3,4}\right]$. Each alternation of the average wind speed introduces a corresponding (positive or negative) wind power increment, which in turn, affects the performance of the grid of Estonian power plants $\left[{ }^{5-7}\right]$. Due to inertial oil-shale thermal power plants, the Estonian grid is especially sensitive to these increments. This paper continues the study of wind speed fronts $\left[{ }^{4}\right]$, which was the first step to assess problems of matching Wind Turbine Generators (WTGs) in the grid. In $\left[{ }^{4}\right]$ we proved, using the data series measured on the Kihnu Island, that the average value of wind speed increments $\Delta u$ is almost independent of the average value of wind speed $u: \Delta u \neq f(u)$. This result is not exceptional, since it is also valid for the Harilaid Islet (Fig. 1). In this figure we 


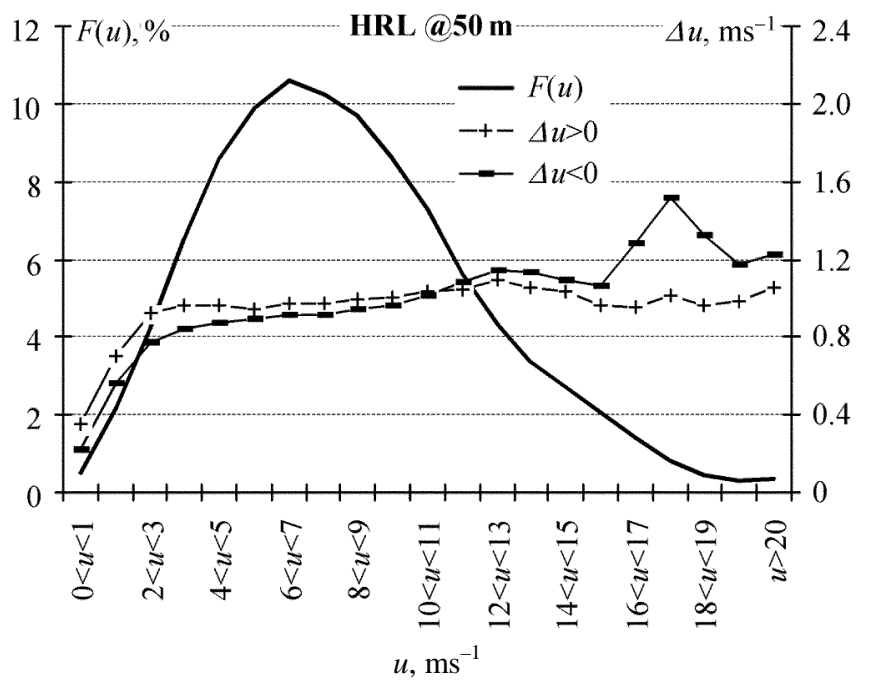

Fig. 1. Behaviour of wind speed and its increments on the Harilaid Islet at $50 \mathrm{~m}$.

show frequency distribution diagram (histogram) of the wind speed $F(u)$ and distribution of positive $(\Delta u>0)$ and negative $(\Delta u<0)$ wind speed increments measured at the Harilaid site. For theoretical analysis, $\Delta u=$ const is used. Below we will prove that the behaviour of the average value of wind power increments differs fundamentally from the behaviour of wind speed increments. In the theoretical work we used wind speed data from the Harilaid Islet at the height of $50 \mathrm{~m}$, recorded in the period from October 1997 to May $1998\left[^{2}\right]$ and the result is compared with the real behaviour of a WTG in Virtsu.

\section{PRINCIPAL DIFFERENCE BETWEEN WIND SPEED AND WIND POWER INCREMENTS}

For theoretical prediction we can consider wind speed increments as independent of the average value of wind speed: $\Delta u=$ const $\neq f(u)$. With this ideal premise we can calculate values for positive $\left(\Delta P^{*}>0\right)$ and negative $\left(\Delta P^{*}<0\right)$ selective wind power increments, corresponding to positive $(\Delta u>0)$ and negative $(\Delta u<0)$ wind speed increments (Fig. 2). Here $P^{*}=P(u) / P_{\text {rated }}$ is the relative capacity of a WTG (ratio or percentage to the rated power) and $F\left(\Delta P^{*}\right)$ is the frequency of its increments, depending on the average value of wind speed. In these calculations we used the non-linear power curve of an average European-made WTG in the range of capacities 1-2 MW:

$$
\begin{gathered}
P^{*}=0, \text { when } u<u_{\text {start }}, \\
P^{*}=\left(u-u_{\text {start }}\right)^{1.75} / 47, \text { when } u_{\text {start }}<u<u_{\text {stab }}, \\
P^{*}=1 \text {, when } u>u_{\text {stab }} .
\end{gathered}
$$




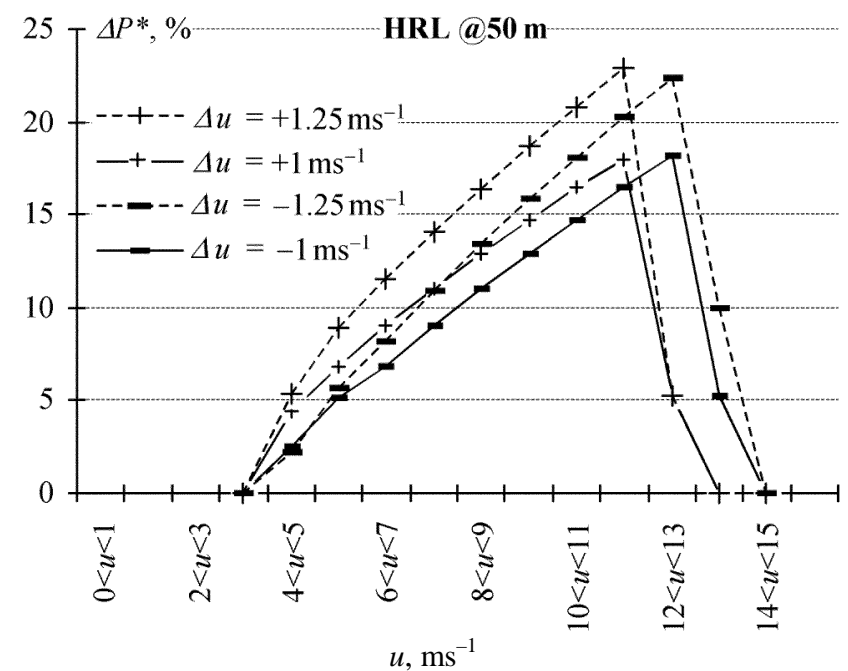

Fig. 2. Theoretical dependence of wind power increments on the average wind speed in the Harilaid Islet based on constant wind speed increments.

Here $u_{\text {start }}=3.75 \mathrm{~ms}^{-1}$ is the wind speed at the start of the WTG and $u_{\text {stab }}=$ $13.99 \mathrm{~ms}^{-1}$ is the wind speed at the stabilization level (kink of the power curve).

This power curve cuts out small and modest wind speed increments in the ranges of low and high wind speed $\left(u<4 \mathrm{~ms}^{-1}\right.$ and $\left.u>14 \mathrm{~ms}^{-1}\right)$. Figure 2 shows the dependence of wind power increments on the average value of wind speed $\Delta P^{*}=f(u)$, which has a form of an unsymmetrical triangle. Maximums of the positive and negative wind power increments do not coincide, while the maximum of negative wind power increments corresponds to a higher wind speed value. Also, we see that values of wind power increments are quite sensitive to the value of average wind speed increments. Therefore, wind power increments will be different while defined as simple or selective wind power increments analogously to $\left[{ }^{4}\right]$. Simple wind power increments $\delta P^{*}$ are defined as a difference of average wind capacities in a one hour interval. Selective wind power increments $\Delta P^{*}$ are defined as the maximum of differences of average wind capacities within a one hour interval, determined by 10-minute time steps. The same approach was used for the wind speed increments: simple wind speed increment $\delta u$ was defined as a difference of average wind speeds in a one hour interval and the selective wind speed increment was defined as a maximum of differences of average wind speeds within a one hour interval, determined by 10minute time steps. If the real wind speed increments depend on the average value of wind speed $(\Delta u=f(u))$, the theoretical diagram in Fig. 2 will be distorted. Such a calculated "real" diagram, based on the real trend of $\Delta u$, is shown in Fig. 3 for the data recorded at the Harilaid Islet $\left[{ }^{2}\right]$. This figure shows the histogram of wind speeds at the height of $50 \mathrm{~m}$ together with the diagrams of positive $\left(\delta P^{*}>0\right)$ and negative $\left(\delta P^{*}<0\right)$ wind power increments. Function $F(u)$ 


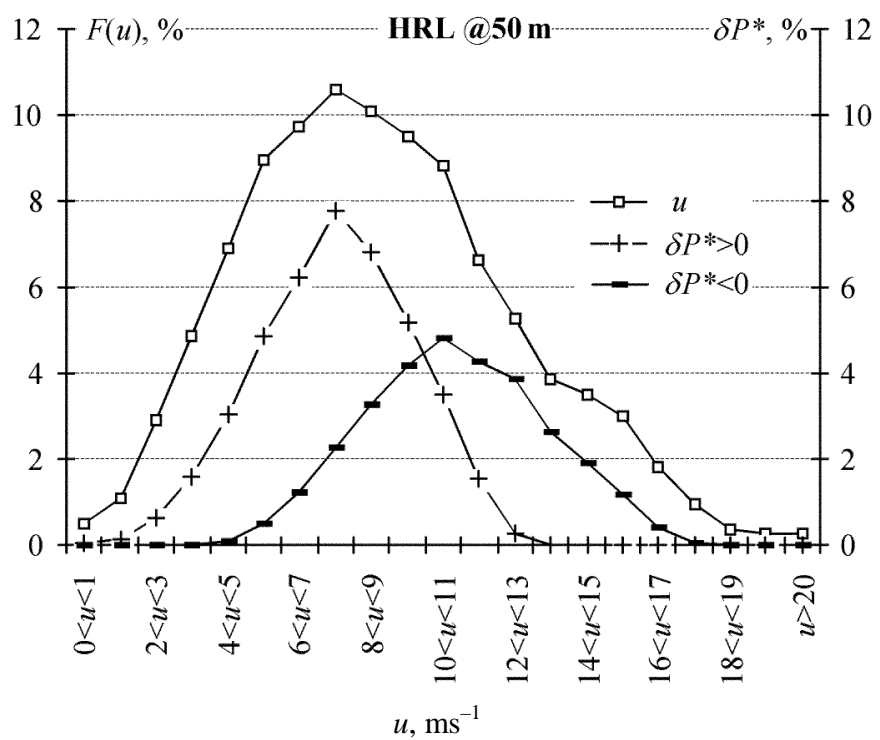

Fig. 3. Calculated positive and negative simple wind power increments at the Harilaid Islet, depending on the average wind speed (based on the real trend of wind speed increments).

expresses the frequency of events at the corresponding value in the brackets. A comparison of Figs. 2 and 3 shows that a correspondence exists between theoretical and experimental data as the maximum of negative power increments is displaced into higher range of average wind speeds in both cases.

\section{REAL WIND POWER INCREMENTS OF THE VIRTSU WIND TURBINE}

Real wind power increments were assessed using the wind capacity data, recorded at the $600 \mathrm{~kW}$ Enercon E-40 wind turbine in the interval from November 2002 to May 2003. Its hub height is $63 \mathrm{~m}$. The data were recorded with a sampling interval of $10 \mathrm{~min}$ and used to calculate simple and selective wind power increments. Figure 4 shows the frequency distribution diagram of both power increments $F\left(\left|\Delta P^{*}\right|,\left|\delta P^{*}\right|\right)$. Here we use the absolute values of the power increments as positive and negative increments have coinciding distributions $\left[{ }^{3,8,9}\right]$. Thus, depending on the value of the increment, difference exists. The frequency of increments defined by the selective method $F\left(\left|\Delta P^{*}\right|\right)>$ $F\left(\left|\delta P^{*}\right|\right)$ is several times higher. This phenomenon is most obvious if we compare 25 highest increments (positive and negative) in Fig. 5. High wind power increments were concentrated at the wind speed range of $10 \mathrm{~ms}^{-1}$. Positive increments had the average wind speed $9.7 \mathrm{~ms}^{-1}$ while negative ones showed an average wind speed $11.5 \mathrm{~ms}^{-1}$. This phenomenon was predicted by the theory. Thus, always $\Delta P^{*}>\delta P^{*}$, frequently $\Delta P^{*}>>\delta P^{*}$ and in some cases $\Delta P^{*}$ and 


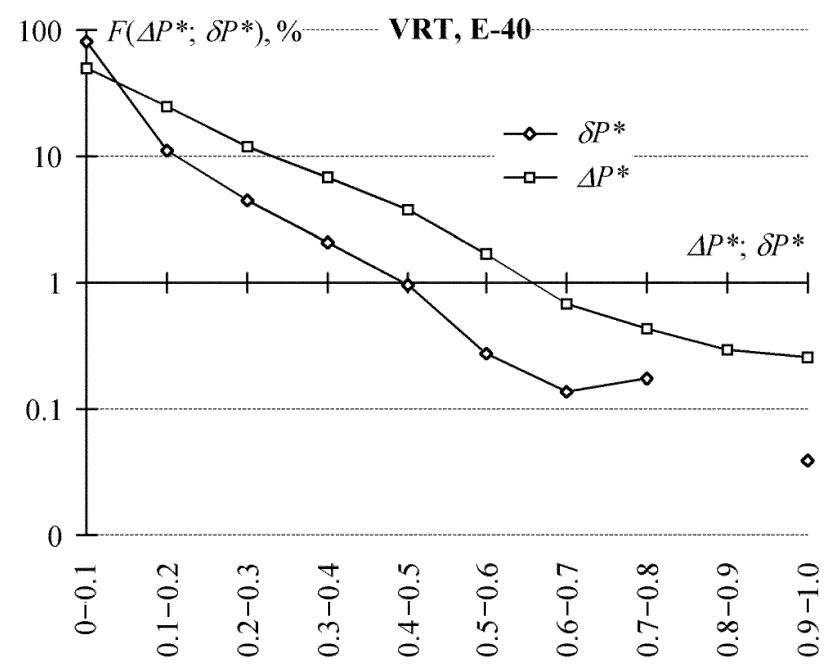

Fig. 4. Distribution of the frequency of simple and selected wind power increments of the Virtsu wind turbine generator.

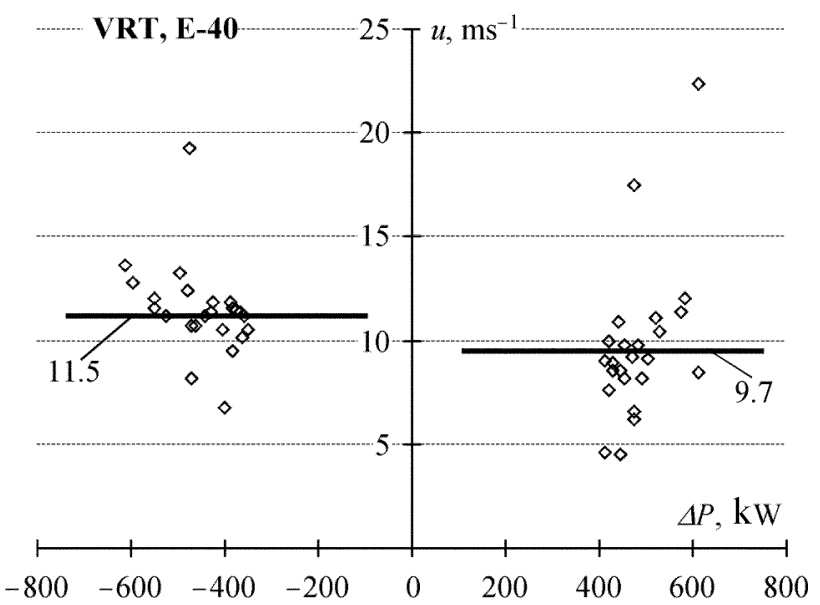

Fig. 5. Relations between high selected positive and negative wind power increments of the Virtsu wind turbine generator.

$\delta P^{*}$ have even a different sign. It means that the wind speed and power data should be recorded as frequently as possible and the selected increment method should be preferred. The averaging interval of $10 \mathrm{~min}$ is long enough for the controller of any WTG to react. It is of interest to compare the theoretical wind power distribution law at the Harilaid site with the real one in Virtsu. The theoretical prognosis in Fig. 2 assumes that the values of wind power increments 


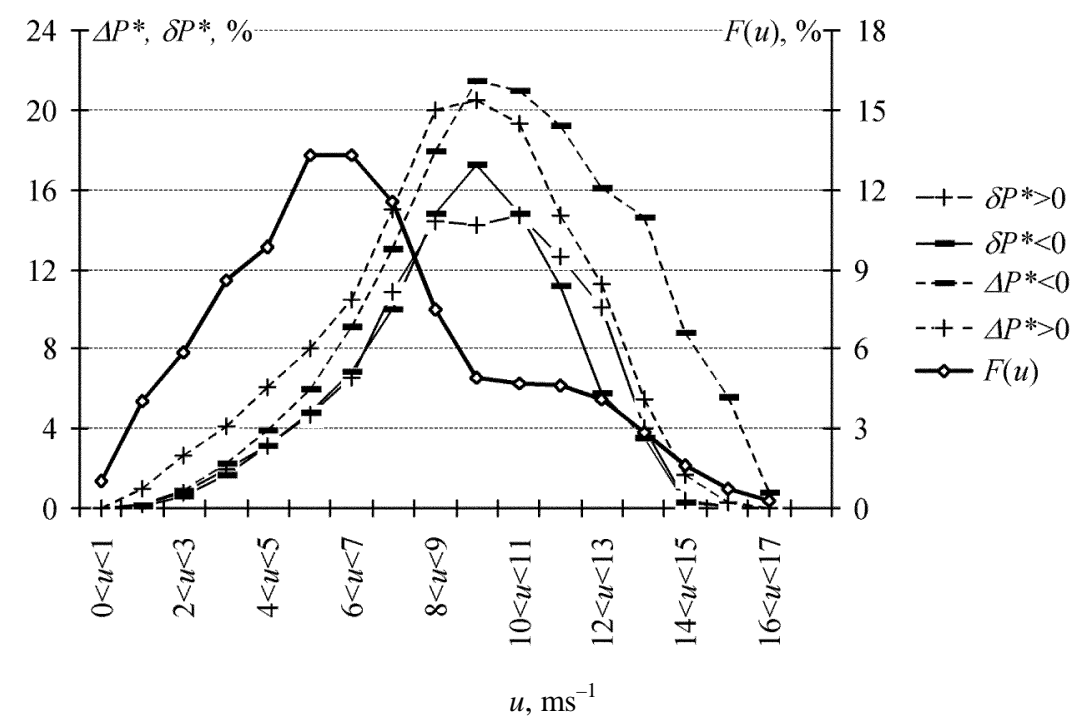

Fig. 6. Real positive and negative simple and selected wind power increments of the Virtsu wind turbine generator, depending on the average wind speed $u$.

decrease faster near the maximum $u>12 \mathrm{~ms}^{-1}$ than they increase in the wind speed range $4<u<12 \mathrm{~ms}^{-1}$, which is confirmed in the practice in Fig. 6. This figure shows histogram of the wind speed $F(u)$ and all discussed wind power increments, assessed for the Virtsu WTG.

\section{ZERO VALUE WIND POWER INCREMENTS}

Wind speed and power increments from the data series measured in Virtsu were selected with conditions $\Delta u<0$ and $\Delta u>0$, respectively (analogously to $\Delta P^{*}<0$ and $\Delta P^{*}>0$ ). In fact, a number of increments exists with $\Delta u=0$ (analogous to $\Delta P^{*}=0$ ), which are not considered. To evaluate their possible frequency, zero value data $\left(\Delta P^{*}=0\right)$ were studied for November 2002. The share of zero values was $56 \%$ and within this amount they were distributed differently. Events $\Delta P^{*}=0$ at the average speed $u \leq 1.9 \mathrm{~ms}^{-1}$ are outside the performance range of the WTG $(64 \%$ of $56 \%)$. If $u \geq 13.1 \mathrm{~ms}^{-1}$, the WTG performed in the range of the power limitation, where $\Delta P^{*}=0$ is a normal situation (27\% of 56\%). Only events at the average wind speed $u=5.6 \mathrm{~ms}^{-1}$ (9\% of 56\%) corresponded to the normal performance range of the WTG, which may lead to errors in the frequency distribution of the increments. The value of errors assessed in this way is low, amounting to about $5 \%$ of all the data analysed, and does not affect the principal relations studied in this work. The events $\Delta P^{*}=0$ while $u=5.6$ are probably caused by the failures of the WTG $\left[{ }^{10}\right]$, adjustment of which was not completed. 


\section{CONCLUSIONS}

1. The average value of wind power increments depends non-linearly on the average value of the wind speed and is close to the asymmetric triangle.

2. The range of negative wind power increments is displaced towards higher wind speeds in contrast to the positive increments.

3. Wind power increments have zero values at low and high average wind speed values. This results from the strongly non-linear power curve of wind turbines.

4. The wind power increments, defined by selective method, differ from their increments, defined by the simple method much more than the corresponding characteristics of the wind speed. In the determination of high wind power increments, the selective increment method shows obvious advantages over the simple increment method, since in the latter some increments may remain unnoticed. However, the unnoticed wind power increments would affect the grid significantly.

5. The frequency of high wind power increments, found by the selective increment method, is much greater than found by the simple increment method.

\section{ACKNOWLEDGEMENT}

Support of the Estonian Science Foundation (grant No. 5051) is appreciated.

\section{REFERENCES}

1. Soomere, T. and Keevallik, S. Anisotropy of moderate and strong winds in the Baltic Proper. Proc. Estonian Acad. Sci. Eng., 2001, 7, 35-49.

2. Tomson, T. and Hansen, M. Wind dynamics in the Moonsund archipelago. Proc. Estonian Acad. Sci. Eng., 2000, 6, 61-69.

3. Tomson, T. and Hansen, M. Influence of wind speed gusts on power generation. Proc. Estonian Acad. Sci. Eng., 2002, 8, 276-285.

4. Tomson, T. and Hansen, M. Behaviour of wind speed fronts. Proc. Estonian Acad. Sci. Eng., $2005,11,215-225$.

5. Lemström, B., Räkkoläinen, J. and Peltola, E. A wind farm's impact on the quality of electricity in a weak network. In Proc. 1999 European Wind Energy Conference, Nice, 1999, 747749 .

6. Liik, O., Oidram, R., Keel, M. et al. Co-operation of Estonian's oil shale based power system with wind turbines. Oil Shale, 2005, 22, 127-142.

7. Brunt, M., Havsager, J. and Knudsen, H. Incorporation of wind power in the East-Danish power system. In Proc. IEE Technology Conference IEE Power. Tech'99. Budapest, 1999.

8. Durstewitz, M., Ensslin, C., Hoppe-Kilpper, M. and Rohrig, K. Electrical power from widelydispersed wind turbines. In Proc. European Wind Energy Conference, Dublin, 1997, $743-$ 746.

9. Tomson, T. and Nõva, A. Geographically dispersed wind turbines on the West-Estonian Coast. CIGR J. Sci. Res. Devel., 2001, 3, EE00 006. 
10. Tomson, T., Hansen, M. and Pirksaar, R. Investigation of the accuracy of prognosed wind energy. In Proc. Conference TEUK-V. Tartu, 2004, 29-35.

\section{Tuulevõimsuse frondid}

\section{Teolan Tomson ja Maire Hansen}

On näidatud, et tuulevõimsuse muutude esinemise seaduspärasused erinevad oluliselt vastavatest tuulekiiruse muutude esinemise seaduspärasustest. Tuulevõimsuse keskmiste muutude sõltuvus tuule keskmisest kiirusest on lähedane ebasümmeetrilisele kolmnurgale, kusjuures tuulevõimsuse muudud puuduvad keskmise tuulekiiruse madalatel ja kõrgetel väärtustel. Seda nähtust põhjustab elektrituuliku võimsuskõvera tugevalt mittelineaarne iseloom. Valikmeetodil leitud tuulevõimsuse muudud on suuremad ja esinevad mitu korda tihedamini, kui neid õnnestub selgitada lihtmuutude meetodil. Töös toodud teoreetilisi tulemusi kinnitavad mõõtmistulemused. 